\title{
Role of C-Reactive Protein and Procalcitonin in Differentiation of Tuberculosis from Bacterial Community Acquired Pneumonia
}

\author{
Young Ae Kang', Sung-Youn Kwon², Ho IL Yoon², Jae Ho Lee', and Choon-Taek Lee² \\ 'Department of Internal Medicine, Yonsei University College of Medicine, Seoul; ${ }^{2}$ Department of Internal Medicine, \\ Respiratory Center, Seoul National University Bundang Hospital, Seongnam, Korea
}

\begin{abstract}
Background/Aims: We investigated the utility of serum C-reactive protein (CRP) and procalcitonin (PCT) for differentiating pulmonary tuberculosis (TB) from bacterial community-acquired pneumonia (CAP) in South Korea, a country with an intermediate TB burden.

Methods: We conducted a prospective study, enrolling 87 participants with suspected CAP in a community-based referral hospital. A clinical assessment was performed before treatment, and serum CRP and PCT were measured. The test results were compared to the final diagnoses.

Results: Of the 87 patients, 57 had bacterial CAP and 30 had pulmonary TB. The median CRP concentration was $14.58 \mathrm{mg} / \mathrm{dL}$ (range, 0.30 to 36.61) in patients with bacterial CAP and $5.27 \mathrm{mg} / \mathrm{dL}$ (range, 0.24 to 13.22) in those with pulmonary TB ( $p<0.001$ ). The median PCT level was $0.514 \mathrm{ng} / \mathrm{mL}$ (range, 0.01 to 27.75 ) with bacterial CAP and $0.029 \mathrm{ng} / \mathrm{mL}$ (range, 0.01 to 0.87 ) with pulmonary TB $(p<0.001)$. No difference was detected in the discriminative values of CRP and PCT $(p=0.733)$.

Conclusions: The concentrations of CRP and PCT differed significantly in patients with pulmonary TB and bacterial CAP. The high sensitivity and negative predictive value for differentiating pulmonary TB from bacterial CAP suggest a supplementary role of CRP and PCT in the diagnostic exclusion of pulmonary TB from bacterial CAP in areas with an intermediate prevalence of pulmonary TB. (Korean J Intern Med 2009;24:337-342)
\end{abstract}

Keywords: C-reactive protein; Pneumonia, community acquired; Procalcitonin; Tuberculosis

\section{INTRODUCTION}

Community-acquired pneumonia (CAP) is a major cause of hospital admission and the most important infectious cause of death [1]. A rapid diagnosis and appropriate antibiotic treatment are essential to reduce the morbidity and mortality from CAP. In countries with a high tuberculosis (TB) burden, Mycobacterium tuberculosis is a frequent cause of CAP [2-4], and the differential diagnosis of TB from common bacterial pneumonia is difficult. The varying clinical and radiographic presentation of $\mathrm{CAP}$ and $\mathrm{TB}$ according to patient age and comorbidity and the low sensitivity of acid-fast bacillus microscopy make it even more difficult to distinguish TB from common bacterial pneumonia [5-7]. Therefore, an adjunct diagnostic method that can determine whether CAP is caused by pulmonary TB or other bacterial pathogens would have a clinical role in terms of isolating patients with $\mathrm{TB}$ and administering appropriate anti-TB medication or antibiotic treatment at an early stage.

C-reactive protein (CRP) is an acute-phase protein and nonspecific marker of systemic inflammation [8]. The ability of the serum CRP concentration to identify the etiology of CAP and to predict the prognosis of CAP has been investigated [9-14]. Procalcitonin (PCT), a 116amino-acid protein, is a useful marker of severe systemic

Received: December 13, 2008

Accepted: March 4, 2009

Correspondence to Choon-Taek Lee, M.D.

Department of Internal Medicine, Respiratory Center, Seoul National University Bundang Hospital, 300 Gumi-dong, Bundang-gu, Seongnam 463-707, Korea

Tel: 82-31-787-7002, Fax: 82-31-787-4052, E-mail: ctlee@snu.ac.kr 
bacterial infection [15-18]. Recently, PCT has also been introduced as a promising alternative to CRP in guiding the antibiotic treatment of CAP and acute exacerbations of chronic obstructive pulmonary disease $[19,20]$ based on the ability of PCT to discriminate between patients with or without bacterial infection. In addition, PCT does not appear to be significantly elevated in patients with pulmonary TB [21-23], making it an attractive potentially rapid diagnostic method for differentiating pulmonary $\mathrm{TB}$ from bacterial CAP.

Therefore, we investigated the utility of serum CRP and PCT for differentiating pulmonary TB from other bacterial CAP in South Korea, a country with an intermediate TB burden. We also investigated whether serum CRP and PCT could help distinguish CAP according to pneumonia severity.

\section{METHODS}

\section{Participants}

Participants were recruited between March 2007 and November 2007 after the study protocol had been approved by the Seoul National University Bundang Hospital Ethics Review Committee. Adult patients who visited the emergency department or outpatient clinic with respiratory symptoms and chest radiograph abnormalities were eligible for enrollment in this study. After providing written informed consent, all participants were enrolled in this study. Of the 115 eligible patients, 28 were excluded because the final diagnosis was inconclusive or they had other diagnoses, such as pulmonary embolism, acute exacerbation of interstitial lung disease, or non-small cell lung cancer. Eighty-seven patients were classified with pulmonary $\mathrm{TB}$ or bacterial CAP. None of the patients in this study was HIV-positive.

Patients were considered to have pulmonary TB when M. tuberculosis was cultured from their sputum or lavage fluid, and the concentration of adenosine deaminase in the effusion was $>65 \mathrm{IU} / \mathrm{dL}$ in lymphocyte-predominant exudative pleural effusions combined with a lung parenchymal lesion. Bacterial CAP was diagnosed when the subjects had clinical signs of pneumonia and a new infiltrate on chest X-ray, and these resolved completely with antibiotic treatment and cultures of sputum or lavage fluid were negative for M. tuberculosis during follow-up. For the microbiologic evaluation of the patients with CAP, we performed sputum Gram stains and cultures, two blood cultures, and urinary antigen assays to detect Legionella pneumophila and Streptococcus pneumoniae.

All participants had a complete physical examination, and blood samples were obtained for measuring CRP and PCT before starting treatment. Additionally, demographic data, a white blood cell (WBC) count and differential, and the Pneumonia Patient Outcomes Research Team (PORT) [24] score were collected. The results of these tests were compared to the final diagnostic group scores.

\section{Methods}

The serum CRP level was measured using an automated latex-enhanced turbidimetric immunoassay in a clinical laboratory within 1 hour of collecting the samples (Dimension; Dade Behring, Newark, DE, USA; TBA20oFR; Toshiba, Tokyo, Japan).

The PCT level was measured using a monoclonal immunoluminometric assay (LIA PCT sensitive; BRAHMS Diagnostica, Berlin, Germany). After separating the serum, it was aliquoted and frozen at $-70^{\circ} \mathrm{C}$ until analyzed. The functional assay sensitivity for PCT with a 20\% inter-assay variation coefficient was $0.05 \mathrm{ng} / \mathrm{mL}$.

\section{Statistics}

Differences between the two groups were tested using the nonparametric Mann-Whitney $U$-test for continuous variables. Pearson's $\chi^{2}$ test or Fisher's exact test was used for categorical variables, and the Spearman rank correlation coefficient was calculated. Optimal cutoffs for predicting pulmonary $\mathrm{TB}$ or bacterial CAP were investigated using receiver-operating characteristics (ROC) analysis, and the diagnostic accuracy was assessed from the area under the ROC curves (AUCs). A $p<0.05$ was regarded as statistically significant, and analyses were performed using SPSS version 15.o (SPSS Inc., Chicago, IL, USA).

\section{RESULTS}

\section{Clinical and laboratory characteristics of the patients}

Of the 87 patients who met the inclusion criteria, 57 had bacterial CAP and 30 had pulmonary TB. The median age of the bacterial CAP and pulmonary TB groups was 71 years (range, 18 to 88 ) and 48 years (range, 18 to 82 ), respectively. The responsible pathogen was determined in 22 patients (38.6\%) with bacterial CAP; nine patients had positive cultures for respiratory secretions and 13 patients 
Table 1. Clinical and laboratory characteristics of the participants

\begin{tabular}{|c|c|c|c|}
\hline & $\begin{array}{l}\text { Bacterial pneumonia } \\
\qquad(\mathrm{n}=57)\end{array}$ & $\begin{array}{l}\text { Tuberculosis } \\
\qquad(n=30)\end{array}$ & $p$ value \\
\hline \multicolumn{4}{|l|}{ Demographic characteristics } \\
\hline Age, yr & $71(18-88)$ & $48(18-82)$ & $<0.001^{*}$ \\
\hline Sex, male/female & $36 / 21$ & $18 / 12$ & $0.77^{\dagger}$ \\
\hline History of tuberculosis & $14(24.6)$ & $6(20.0)$ & $0.63^{\dagger}$ \\
\hline \multicolumn{4}{|l|}{ Symptoms } \\
\hline Cough & $43(75.4)$ & $27(90.0)$ & $0.10^{\dagger}$ \\
\hline Sputum & $48(84.2)$ & $22(73.3)$ & $0.22^{\dagger}$ \\
\hline Fever & $52(91.2)$ & $15(50.0)$ & $<0.001^{\dagger}$ \\
\hline Dyspnea & $34(59.6)$ & $12(40.0)$ & $0.08^{\dagger}$ \\
\hline Night sweats & $0(0)$ & $7(23.3)$ & $<0.001^{\ddagger}$ \\
\hline Weight loss & $1(1.8)$ & $8(26.7)$ & $0.001^{\ddagger}$ \\
\hline Chest pain & $11(19.3)$ & $9(30.0)$ & $0.30^{\dagger}$ \\
\hline \multicolumn{4}{|l|}{ Laboratory test } \\
\hline White blood cell, $\times 10^{3} / \mu \mathrm{L}$ & $13.21(2.29-39.92)$ & $8.38(5.07-22.99)$ & $<0.001$ \\
\hline Neutrophils, $\times 10^{3} / \mu \mathrm{L}$ & $11.06(1.70-37.92)$ & $5.85(3.07-20.23)$ & $<0.001^{*}$ \\
\hline Monocyte, $\mu \mathrm{L}$ & $503(0-1210)$ & $535(253-5009)$ & $0.053 *$ \\
\hline C-reactive protein, $\mathrm{mg} / \mathrm{dL}$ & $14.58(0.30-36.61)$ & $5.27(0.24-13.22)$ & $<0.001 *$ \\
\hline Procalcitonin, ng/mL & $0.514(0.013-27.754)$ & $0.029(0.01-0.873)$ & $<0.001 *$ \\
\hline \multicolumn{4}{|l|}{ Radiographic findings } \\
\hline Upper lobe dominance & $16(28.1)$ & $23(76.7)$ & $<0.001^{\dagger}$ \\
\hline Cavitary lesion & $0(0)$ & $11(36.7)$ & $<0.001^{\ddagger}$ \\
\hline Effusion & $11(19.3)$ & $9(30.0)$ & $0.26^{\dagger}$ \\
\hline PORT score & $87(18-187)$ & $54.5(10-126)$ & $<0.001^{*}$ \\
\hline
\end{tabular}

Values are presented as number (\%) or median (range). PORT, Pneumonia Patient Outcomes Research Team.

* Mann-Whitney U-test.

${ }^{\dagger}$ Pearson $\chi^{2}$ test.

‡Fisher's exact test.

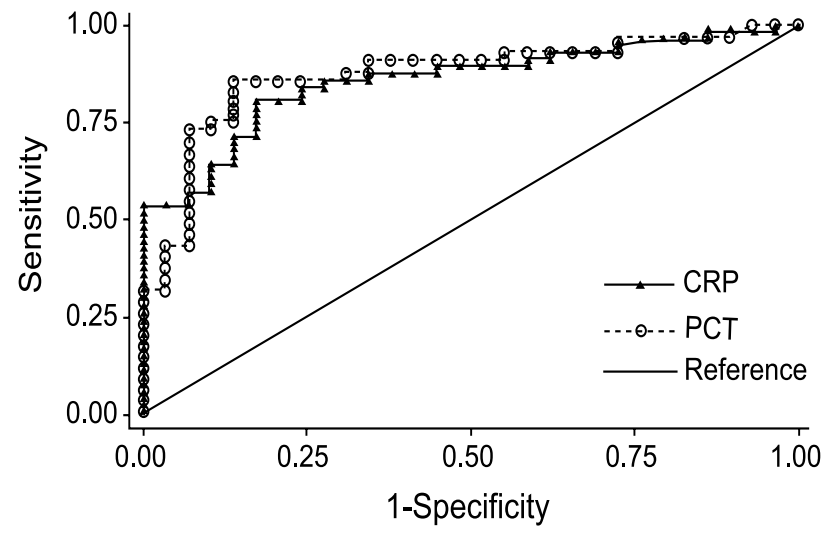

Figure 1. Receiver-operating characteristics curve for discriminating between pulmonary tuberculosis and bacterial community-acquired pneumonia for C-reactive protein (CRP) and procalcitonin (PCT). No difference was detected in the discriminative value between CRP and PCT. had positive urinary pneumococcal antigen tests. Twentyseven patients (90\%) with pulmonary TB had positive respiratory specimen cultures for $M$. tuberculosis. The patients' demographic characteristics, symptoms, and laboratory results are compared in Table 1.

The median CRP concentration was $14.58 \mathrm{mg} / \mathrm{dL}$ (range, 0.30 to 36.61 ) in patients with bacterial CAP and $5.27 \mathrm{mg} / \mathrm{dL}$ (range, 0.24 to 13.22) in those with pulmonary TB $(p<0.001)$. The respective median PCT level was $0.514 \mathrm{ng} / \mathrm{mL}$ (range, 0.013 to 27.754 ) and 0.029 $\mathrm{ng} / \mathrm{mL}$ (range, 0.01 to 0.873 ) $(p<0.001)$. A significant positive correlation was detected between the CRP and PCT concentrations $(r=0.648, p=0.01)$.

\section{Diagnostic accuracy for discriminating TB from bacterial CAP}

In the ROC curve analysis, the CRP concentration had a 
Table 2. Diagnostic validity of C-reactive protein (CRP) and procalcitonin (PCT) in differentiating pulmonary tuberculosis from bacterial community-acquired pneumonia according to the different value

\begin{tabular}{lcccc}
\hline & Sensitivity & Specificity & Positive predictive value & Negative predictive value \\
\hline $\begin{array}{l}\text { CRP, } \mathrm{mg} / \mathrm{dL} \\
<5.0\end{array}$ & & & & \\
$<10.0$ & 50.0 & 89.3 & 71.4 & 76.9 \\
$<12.5$ & 83.3 & 75.0 & 64.1 & 89.4 \\
$<15.0$ & 90.0 & 58.9 & 54.0 & 91.7 \\
$\mathrm{PCT}, \mathrm{ng} / \mathrm{mL}$ & 100.0 & 50.0 & 51.7 & 100.0 \\
$<0.1$ & & & & \\
$<0.25$ & 86.2 & 78.9 & 67.6 & 91.8 \\
$<0.5$ & 93.1 & 59.6 & 54.0 & 94.4 \\
$<1.0$ & 93.1 & 50.9 & 49.1 & 93.5 \\
& 100.0 & 31.6 & 42.6 & 100.0 \\
\hline
\end{tabular}

Values are presented as percentages.
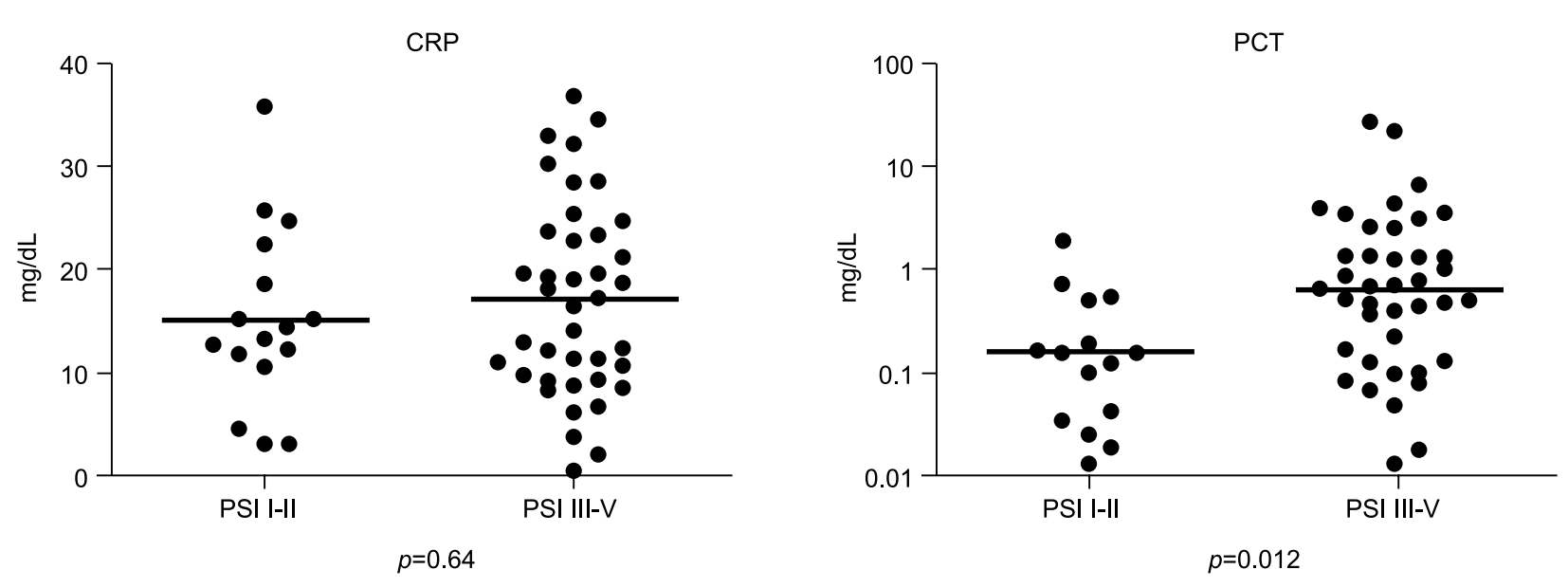

Figure 2. C-reactive protein (CRP) and procalcitonin (PCT) concentration according to the pneumonia severity index in bacterial community-acquired pneumonia. Patients in risk classes III and V had a higher median PCT value compared to those in classes I and II, whereas no significant difference was observed in the CRP concentrations between those groups classified as Pneumonia Severity Index (PSI) I-II or PSI III-V.

discriminative value of 0.857 (95\% confidence interval [CI], 0.778 to 0.936), and the PCT concentration had a discriminative value of 0.872 ( $95 \%$ CI, 0.792 to 0.951 ). No difference was found in the discriminative value between CRP and PCT ( $p=0.733)$. At a cutoff value of $12.5 \mathrm{mg} / \mathrm{dL}$, the CRP concentration had a sensitivity of $90.0 \%$ and a specificity of $58.9 \%$; at a cutoff value of $0.25 \mathrm{ng} / \mathrm{mL}$, the PCT concentration had a sensitivity of $93.1 \%$ and a specificity of $59.6 \%$ (Fig. 1, Table 2).

\section{CRP and PCT concentrations according to the PORT Pneumonia Severity Index (PSI) risk classes}

The median CRP and PCT concentrations were calculated according to the PSI risk class in the bacterial CAP group.
The respective median CRP and PCT values were 3.8 $\mathrm{mg} / \mathrm{dL}$ (range, 3.04 to 11.63 ) and $0.023 \mathrm{ng} / \mathrm{mL}$ (range, 0.013 to 1.974 ) in class I, $15.0 \mathrm{mg} / \mathrm{dL}$ (range, 10.48 to 35.63 ) and $0.164 \mathrm{ng} / \mathrm{mL}$ (range, 0.035 to 1.609 ) in class II, $18.9 \mathrm{mg} / \mathrm{dL}$ (range, 0.30 to 32.85 ) and $0.723 \mathrm{ng} / \mathrm{mL}$ (range, 0.013 to 3.279 ) in class III, $12.0 \mathrm{mg} / \mathrm{dL}$ (range, 3.55 to 34.42 ) and $0.707 \mathrm{ng} / \mathrm{mL}$ (range, 0.018 to 22.994 ) in class IV, and $18.3 \mathrm{mg} / \mathrm{dL}$ (range, 8.52 to 36.61 ) and $0.525 \mathrm{ng} / \mathrm{mL}$ (range, 0.049 to 27.754 ) in class V. Patients in risk classes III-V had a higher median PCT value of $0.659 \mathrm{ng} / \mathrm{mL}$ (range, 0.013 to 27.754 ) compared to 0.159 $\mathrm{ng} / \mathrm{mL}$ (range, 0.013 to 1.974) for those in classes I and II ( $p=0.012$ ), whereas no significant difference was observed in the CRP concentrations between those groups classified 
with PSI I-II or PSI III-V (Fig. 2).

\section{DISCUSSION}

The results of this study suggest that CRP and PCT can help to discriminate between pulmonary TB and other common bacterial CAP in a setting of intermediate TB prevalence. Significantly lower CRP and PCT serum concentrations were found with pulmonary $\mathrm{TB}$ compared to the other bacterial CAP in the initial diagnosis stage. About 46,000 cases of TB are newly diagnosed annually in South Korea [25], and the rapid, accurate differential diagnosis of TB from common bacterial CAP has important public health implications for the isolation care of patients with TB and early appropriate anti-TB medication or antibiotic treatment. Discriminating pulmonary TB from bacterial CAP is frequently impossible based on patient history, physical examination, and radiographic findings. Therefore, CRP and PCT might have a role in the diagnostic algorithm as rapid, noninvasive tests.

No difference was observed in the discriminating power of CRP and PCT for differentiating pulmonary TB and other bacterial infections in this study. CRP is an acutephase protein and nonspecific marker for systemic inflammation, and the utility of CRP level as a marker for bacterial infection of the lower respiratory tract has been studied in several populations [26]. PCT has also been investigated as a predictor of bacterial infection and is considered a more accurate marker of various bacterial infections than CRP $[16,27]$. Therefore, the absence of a difference between CRP and PCT in our study should be considered in light of several factors. First, the low yield of a causative pathogen in bacterial CAP (38.6\%) suggests the possibility of including bacterial CAP with an atypical etiology, such as Mycoplasma pneumoniae, Chlamydia pneumoniae, and respiratory viruses. These atypical pathogens produce lower PCT levels than classical bacterial pneumonia such as pneumococcal pneumonia [11,28]. Second, because the hospital in which this study was conducted is a secondary referral hospital, although it is a community-based hospital, more than 24 hours had passed from the onset of symptoms to the time some patients visited the hospital. The variable time interval from the onset of symptoms before evaluating PCT and CRP might have affected the results because of the kinetics of each inflammatory marker [29,30]. Considering this point, a follow-up PCT or CRP measurement after the initial evaluation will affect the treatment strategy.

Although we found no difference in the discriminating power of CRP and PCT for distinguishing pulmonary TB from bacterial infection, our results showed the superiority of PCT for predicting the severity of bacterial CAP compared to CRP. This is consistent with the finding that PCT is a good predictor of the severity of pneumonia and sepsis, as described previously [31,32], and implies that PCT can be used effectively for site-of-care decisions and for predicting CAP prognosis based on clinical considerations [33].

To appreciate our results fully, we must consider the limitations of this study. First, the patients with pulmonary $\mathrm{TB}$ were younger than those with bacterial CAP, and few had far-advanced disease; this was reflected in the difference in the PORT score between patients with pulmonary TB and those with bacterial CAP. Further study, including a study of advanced pulmonary TB, might complement our study. Second, the low yield of possible pathogens in bacterial CAP and the small number of study subjects should be considered when generalizing the results using CRP and PCT to determine pulmonary TB and bacterial CAP.

In conclusion, serum CRP and PCT concentrations differed significantly in patients with pulmonary TB and those with bacterial CAP at the initial diagnosis stage. The high sensitivity and negative predictive value for differentiating the diagnosis of pulmonary TB from bacterial CAP suggest a supplementary role for CRP and PCT in the diagnostic exclusion of pulmonary TB from bacterial CAP in areas with an intermediate prevalence of active pulmonary $\mathrm{TB}$.

\section{REFERENCES}

1. Marrie TJ. Community-acquired pneumonia. Clin Infect Dis 1994;18:501-513.

2. Ishida T. Etiology of community-acquired pneumonia among adult patients in Japan. Jpn J Antibiot 2000;53(Suppl B):3-12.

3. Scott JA, Hall AJ, Muyodi C, et al. Aetiology, outcome, and risk factors for mortality among adults with acute pneumonia in Kenya. Lancet 2000;355:1225-1230.

4. Liam CK, Pang YK, Poosparajah S. Pulmonary tuberculosis presenting as community-acquired pneumonia. Respirology 2006;11:786-792.

5. Kiyan E, Kilicaslan Z, Gurgan M, Tunaci A, Yildiz A. Clinical and radiographic features of pulmonary tuberculosis in non-AIDS immunocompromised patients. Int J Tuberc Lung Dis 2003;7: 
764-770.

6. Perez-Guzman C, Torres-Cruz A, Villarreal-Velarde H, SalazarLezama MA, Vargas MH. Atypical radiological images of pulmonary tuberculosis in 192 diabetic patients: a comparative study. Int J Tuberc Lung Dis 2001;5:455-461.

7. Lieberman D, Lieberman D, Schlaeffer F, Porath A. Communityacquired pneumonia in old age: a prospective study of 91 patients admitted from home. Age Ageing 1997;26:69-75.

8. Black S, Kushner I, Samols D. C-reactive protein. J Biol Chem 2004;279:48487-48490.

9. Almirall J, Bolibar I, Toran P, et al. Contribution of C-reactive protein to the diagnosis and assessment of severity of communityacquired pneumonia. Chest 2004;125:1335-1342.

10. Kerttula Y, Leinonen M, Koskela M, Makela PH. The aetiology of pneumonia: application of bacterial serology and basic laboratory methods. J Infect 1987;14:21-30.

11. Hedlund J, Hansson LO. Procalcitonin and C-reactive protein levels in community-acquired pneumonia: correlation with etiology and prognosis. Infection 2000;28:68-73.

12. Castro-Guardiola A, Armengou-Arxe A, Viejo-Rodriguez A, Penarroja-Matutano G, Garcia-Bragado F. Differential diagnosis between community-acquired pneumonia and non-pneumonia diseases of the chest in the emergency ward. Eur J Intern Med 2000;11:334-339.

13. Smith RP, Lipworth BJ, Cree IA, Spiers EM, Winter JH. Creactive protein: a clinical marker in community-acquired pneumonia. Chest 1995;108:1288-1291.

14. Ortqvist A, Hedlund J, Wretlind B, Carlstrom A, Kalin M. Diagnostic and prognostic value of interleukin-6 and C-reactive protein in community-acquired pneumonia. Scand J Infect Dis 1995;27:457-462.

15. Uzzan B, Cohen R, Nicolas P, Cucherat M, Perret GY. Procalcitonin as a diagnostic test for sepsis in critically ill adults and after surgery or trauma: a systematic review and meta-analysis. Crit Care Med 2006;34:1996-2003.

16. Simon L, Gauvin F, Amre DK, Saint-Louis P, Lacroix J. Serum procalcitonin and C-reactive protein levels as markers of bacterial infection: a systematic review and meta-analysis. Clin Infect Dis 2004;39:206-217.

17. Muller B, Becker KL. Procalcitonin: how a hormone became a marker and mediator of sepsis. Swiss Med Wkly 2001;131:595602.

18. de Werra I, Jaccard C, Corradin SB, et al. Cytokines, nitrite/ nitrate, soluble tumor necrosis factor receptors, and procalcitonin concentrations: comparisons in patients with septic shock, cardiogenic shock, and bacterial pneumonia. Crit Care Med 1997;25:607-613.
19. Stolz D, Christ-Crain M, Bingisser R, et al. Antibiotic treatment of exacerbations of COPD: a randomized, controlled trial comparing procalcitonin-guidance with standard therapy. Chest 2007;131:9-19.

20.Christ-Crain M, Stolz D, Bingisser R, et al. Procalcitonin guidance of antibiotic therapy in community-acquired pneumonia: a randomized trial. Am J Respir Crit Care Med 2006;174:84-93.

21. Polzin A, Pletz M, Erbes R, et al. Procalcitonin as a diagnostic tool in lower respiratory tract infections and tuberculosis. Eur Respir J 2003;21:939-943.

22. Lawn SD, Obeng J, Acheampong JW, Griffin GE. Serum procalcitonin concentrations in patients with pulmonary tuberculosis. Trans R Soc Trop Med Hyg 1998;92:540-541.

23. Schleicher GK, Herbert V, Brink A, et al. Procalcitonin and Creactive protein levels in HIV-positive subjects with tuberculosis and pneumonia. Eur Respir J 2005;25:688-692.

24. Fine MJ, Auble TE, Yealy DM, et al. A prediction rule to identify low-risk patients with community-acquired pneumonia. N Engl J Med 1997;336:243-250.

25. World Health Organization. Global Tuberculosis Control: Surveillance, Planning, Financing (WHO/HTM/TB/2007.376). WHO Report 2007. Geneva: World Health Organization, 2007.

26.van der Meer V, Neven AK, van den Broek PJ, Assendelft WJ. Diagnostic value of $C$ reactive protein in infections of the lower respiratory tract: systematic review. BMJ 2005;331:26.

27. Muller B, Harbarth S, Stolz D, et al. Diagnostic and prognostic accuracy of clinical and laboratory parameters in communityacquired pneumonia. BMC Infect Dis 2007;7:10.

28. Moulin F, Raymond J, Lorrot M, et al. Procalcitonin in children admitted to hospital with community acquired pneumonia. Arch Dis Child 2001;84:332-336.

29. Pepys MB, Hirschfield GM. C-reactive protein: a critical update. J Clin Invest 2003;111:1805-1812.

30.Dandona P, Nix D, Wilson MF, et al. Procalcitonin increase after endotoxin injection in normal subjects. J Clin Endocrinol Metab 1994;79:1605-1608.

31. Hausfater P, Garric S, Ayed SB, Rosenheim M, Bernard M, Riou B. Usefulness of procalcitonin as a marker of systemic infection in emergency department patients: a prospective study. Clin Infect Dis 2002;34:895-901.

32. Masia M, Gutierrez F, Shum C, et al. Usefulness of procalcitonin levels in community-acquired pneumonia according to the patients outcome research team pneumonia severity index. Chest 2005;128:2223-2229.

33. Mandell LA, Wunderink RG, Anzueto A, et al. Infectious Diseases Society of America/American Thoracic Society consensus guidelines on the management of community-acquired pneumonia in adults. Clin Infect Dis 2007;44(Suppl 2):S27-S72. 